\title{
Effect of Alcohol Consumption on the Sperm DNA Integrity: A Systematic Review
}

\author{
Farah Hanan Fathihah Jaffar ${ }^{1}$, Khairul Osman ${ }^{2}$, Jaya Kumar ${ }^{1} \&$ Siti Fatimah Ibrahim ${ }^{1}$ \\ ${ }^{1}$ Department of Physiology, Universiti Kebangsaan Malaysia Medical Centre, Kuala Lumpur, Malaysia \\ ${ }^{2}$ Centre of Diagnostic Science and Applied Health, Faculty of Health Sciences, Universiti Kebangsaan Malaysia, \\ Kuala Lumpur, Malaysia \\ Correspondence: Siti Fatimah Ibrahim, Department of Physiology, Universiti Kebangsaan Malaysia Medical \\ Centre, Jalan Yaacob Latif, Bandar Tun Razak, 56000 Cheras, Wilayah Persekutuan, Kuala Lumpur, Malaysia. \\ Tel: 60-391-458-615. Fax: 60-326-938-717. E-mail: timi@ukm.edu.my
}

Received: October 3, 2017

Accepted: December 8, 2017 Online Published: December 31, 2017

doi:10.5539/jas.v9n13p136

URL: https://doi.org/10.5539/jas.v9n13p136

\begin{abstract}
There is no solid conclusion on the conventional sperm parameters in association with alcohol consumption, evaluation of sperm DNA integrity thus become a more reliable parameter. Hereby, this literature search was performed to summarize alcohol consumption on the sperm DNA integrity. A computerized database search was done through MEDLINE via Ovid (since 1946 until August 2017) and Cochrane was used. The following set of keywords: 'alcohol consumption OR alcohol intake OR alcohol diet OR drinking alcohol OR ethanol diet' AND 'sperm DNA OR sperm chromatin OR sperm genome OR sperm histone OR sperm protamine' were utilised. 24 articles were retrieved where only five studies conform to the inclusion criteria All studies demonstrated a negative effect of alcohol consumption on sperm DNA integrity, regardless of various range of alcohol doses and duration of alcohol consumption. Out of five studies reviewed, four studies were using a different approach to measure the sperm DNA damage. Hereby, this review identified a need to use a single approach of DNA damage test by having various method of alcohol administration and/or vice versa so that the extension of sperm DNA damage to alcohol consumption will have a better conclusion. On the same note, a few studies have reported the reversibility on conventional semen parameters, none has been done on the sperm DNA damage upon alcohol withdrawal. Therefore, the role of alcohol withdrawal on the reversibility of sperm DNA damage needs to be as well investigated further.
\end{abstract}

Keywords: alcohol consumption, ethanol diet, sperm DNA, sperm chromatin, sperm genome

\section{Introduction}

Alcohol consumption has consistently been demonstrated to deteriorate male fertility. Studies on both human and animal laboratories have scientifically demonstrated that alcohol consumption impaired hypothalamic-pituitarygonadal (HPG) axis (Little et al., 1992; Maneesh et al., 2006), reduced testosterone level in the testes (Muthusami \& Chinnaswamy, 2005) and diminished sperm quality. The sperm quality that are tremendously affected include, sperm concentration (Martini et al., 2004; Condorelli et al., 2014), morphological abnormalities (Joo et al., 2012) and sperm motility (Gaur et al., 2010). These finding were reported contrarily across other studies where they find no association between alcohol consumption and sperm quality (Kunzle et al., 2003; Teijon et al., 2007; Li et al., 2009; Hansen et al., 2012; Povey et al., 2012; Jensen et al., 2014).

Due to this variation, the conventional sperm parameters may therefore do not reflect the true quality of the spermatozoa in association of alcohol intake. Agarwal and Allamaneni (2005) supported this fact where they found approximately $15 \%$ of male with fertility problem presented with normal sperm parameters (Agarwal \& Allamaneni, 2005). In this case, assessment of sperm DNA damage seems to be a more precise tool in diagnosis infertility in male.

Hereby, this systematic review was done in order to summarize the available information regarding the effect of alcohol consumption on the sperm DNA integrity based on preclinical and clinical evidences. Subsequently, we would like to point out where is needed for further research in the future. 


\section{Methods}

\subsection{Search Strategy}

A computerized literature search was conducted on the reported article regarding the effect of alcohol consumption on the status of sperm DNA integrity in particular. The literature research was conducted through MEDLINE via Ovid (1946 until August 2017) and COCHRANE databases with the following keywords: 'alcohol consumption OR alcohol intake OR alcohol diet OR drinking alcohol OR ethanol diet' AND 'sperm DNA OR sperm chromatin OR sperm genome OR sperm histone OR sperm protamine'.

\subsection{Study Inclusion and Exclusion Criteria}

The eligible articles were reviewed independently by two authors (FHF and SFI) based on preclinical and clinical evidences. The following criteria were considered: original article published full-length in English; there is a group of sample that consumed solely alcohol regardless of any fertility factors measured as confounding; measurement of sperm DNA integrity, chromatin packaging and/or DNA breakage as the dependent variables.

\subsection{Data Extraction and Management}

Selection of the study involved two phases. During the first phase, the titles and abstract were scrutinized thoroughly. Following this, the study that did not meet the inclusion criteria were immediately excluded. Full articles were obtained for the remaining list that were likely to meet the selection criteria. Inclusion and exclusion criteria were finalized upon examination of the full articles. Any opinion opposition regarding the inclusion and exclusion criteria were resolved by third reviewer $(\mathrm{KO})$ consensus.

For this review, we recorded the sample size that was related only to alcohol consumption, dose and duration of alcohol consumed, the age of animal sample or human subject, sperm DNA assay type, cut off point of DNA damage and sperm DNA test results in relation to alcohol consumption.

\section{Results}

\subsection{Studies Selected}

Two databases searched successfully retrieved 24 papers. Only one article was removed over duplication. Further 18 articles were excluded (Bjelakovic et al., 2012; Chen \& Lina, 2016; Consales et al., 2014; Farquhar et al., 2017; Garolla et al., 2014; Hart et al., 2015; Li et al., 2016; MacArthur et al., 2014; Nicoletti et al., 2016; Nisenblat et al., 2016; Pourmand et al., 2014; Povey et al., 2012; Rubes et al., 1998; Showell et al., 2013; Showell et al., 2014; Skalkidou et al., 2017; Van et al., 2017; Varshini et al., 2012) after reviewing the titles and abstracts. Full papers were obtained for the remaining 5 articles and reviewing were done thoroughly (Figure 1). 


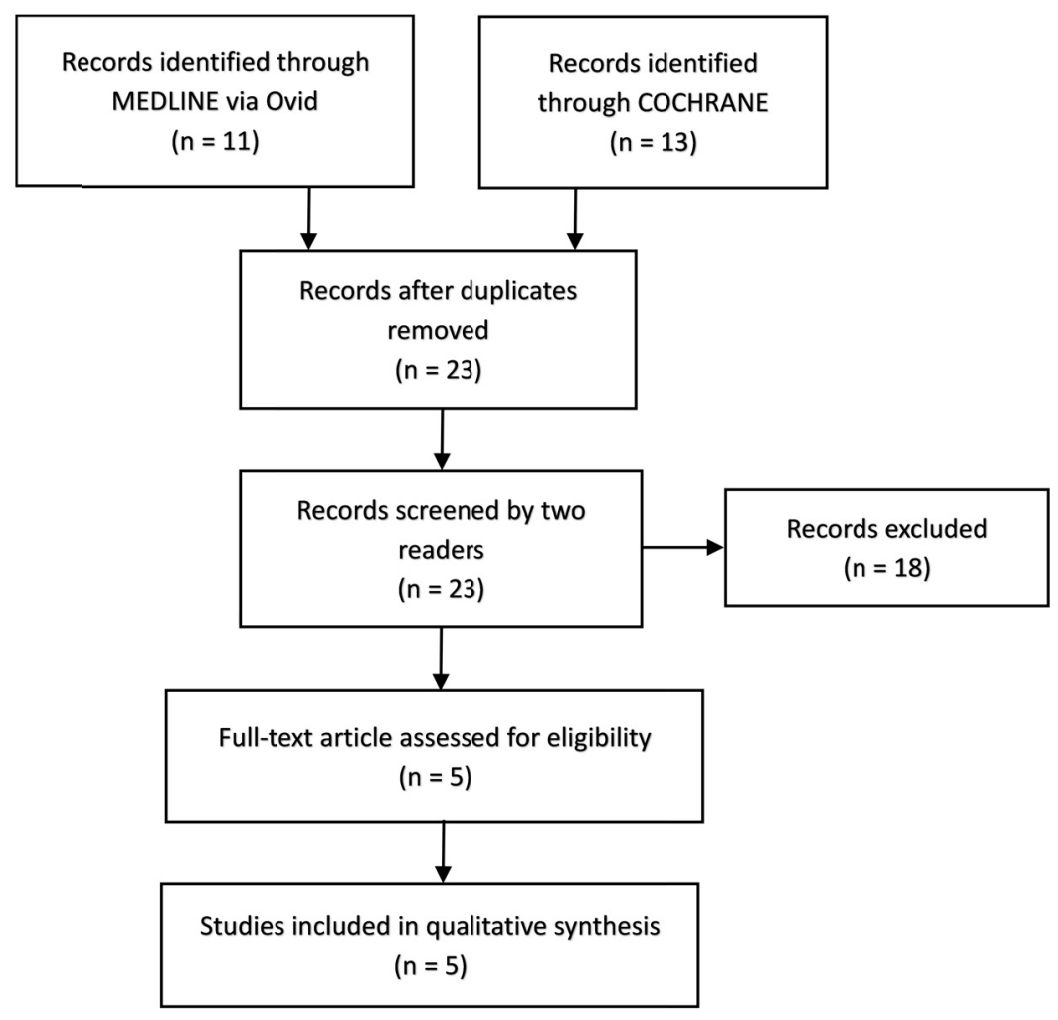

Figure 1. Flow chart of the literature search

\subsection{Study Characteristics}

Of the five eligible papers, three were reported on the effect of alcohol consumption in rats and mice while the other two were reported on human sperm DNA. All reviewed studies have a different approach on measuring DNA integrity with one study reported that the DNA migrated farther in the rats consuming alcohol compared to control group by using pulse field electrophoresis (Abel, 1989). However statistical analysis was not stated to measure the differences. Two studies have evaluated the sperm DNA integrity by using aniline blue (AB), chromomycin A3 (CMA3), toluidine blue (TB) and acridine orange (AO) in Wistar rats and mice respectively (Talebi et al., 2011; Pourentezari et al., 2016). These two studies have demonstrated the same result in alcohol consumption group in which $\mathrm{CMA} 3, \mathrm{~TB}$ and $\mathrm{AO}$ showed significant result compared to control group. On the other hand, $\mathrm{AB}$ does not show significant result compared to control group. Of these two studies, one includes diabetes as a confounding factor (Pourentezari et al., 2016). All three reviewed studies of alcohol consumption use 10-weeks age of rodents but with different doses of alcohol and alcohol treatment period.

Two studies of alcohol consumption on human also reported a direct association of alcohol consumption with DNA fragmentation. Of these two studies, one reported the significant difference of DNA damage between moderate and heavy alcohol consumption but not significantly difference with non-alcoholic group. The evaluation of DNA damage in this study was done by using sperm chromatin dispersion assay kit, Halosperm ${ }^{\circledR}$ in human age $37.43 \pm 0.3$ in average with cigarette smoking as a confounding factors (Anifandis et al., 2014). Another study on human was done on methylation of DNA bases by using PCR sequencing (Ouko et al., 2009). This study demonstrated an increase of demethylation in heavy alcohol consumption group compared to nondrinking alcohol group at 2 imprinted loci which are normally hypermethylated. The age for subject use in this study was range between 19 to 40 years old. Definition of moderate and heavy alcohol consumption in both study was slightly different. The association of alcohol consumption and sperm DNA damage reviewed were depicted in Table 1. 
Table 1. Characteristic of studies on sperm DNA damage in association with alcohol consumption in preclinical and clinical sample

\begin{tabular}{|c|c|c|c|c|c|c|c|c|}
\hline $\begin{array}{l}\text { Author \& } \\
\text { Years }\end{array}$ & $\begin{array}{l}\text { Sample/ } \\
\text { Subject }\end{array}$ & $\begin{array}{l}\text { n for alcohol } \\
\text { consumption } \\
\text { group only }\end{array}$ & Type of study & $\begin{array}{l}\text { Age of } \\
\text { sample/ } \\
\text { subject }\end{array}$ & $\begin{array}{l}\text { Mode of alcohol } \\
\text { administration/ } \\
\text { Measurement of } \\
\text { alcohol intake }\end{array}$ & DNA test & Cut off point & $\begin{array}{l}\text { Association of alcohol } \\
\text { administration and } \\
\text { sperm DNA damage }\end{array}$ \\
\hline $\begin{array}{l}\text { Abel } \\
(1989)\end{array}$ & Long-Evans & Not stated & $\begin{array}{l}\text { Experimental } \\
\text { study }\end{array}$ & 10 weeks & $\begin{array}{l}\text { Liquid diet, } 0 \% \& \\
35 \%, 120 \text { days }\end{array}$ & $\begin{array}{l}\text { Pulsed field } \\
\text { electrophoresis }\end{array}$ & Not mentioned & $\begin{array}{l}\text { DNA taken from sperm of } \\
\text { Long-Evans males } \\
\text { consuming alcohol, migrated } \\
\text { farther under pulsed field } \\
\text { electrophoresis than DNA } \\
\text { from contol fathers. A } \\
\text { difference of about } 50 \\
\text { kilobase pairs was noted. }\end{array}$ \\
\hline \multirow[t]{4}{*}{$\begin{array}{l}\text { Talebi et al. } \\
\text { (2011) }\end{array}$} & \multirow{4}{*}{$\begin{array}{l}\text { Cauda } \\
\text { epipidymal } \\
\text { spermatozoa } \\
\text { of Wistar rat }\end{array}$} & \multirow[t]{4}{*}{10} & \multirow[t]{4}{*}{$\begin{array}{l}\text { Experimental } \\
\text { study }\end{array}$} & \multirow[t]{4}{*}{10 weeks } & \multirow[t]{4}{*}{$\begin{array}{l}\text { Drinking water, } 5 \% \\
(\mathrm{v} / \mathrm{v}), 50 \text { days }\end{array}$} & $\mathrm{AB}$ & Not mentioned & $\begin{array}{l}\mathrm{AB}+\text { not significant } \\
\text { compared to control group }\end{array}$ \\
\hline & & & & & & CMA3 & $30 \%$ & $\begin{array}{l}\text { CMA3+ below cut off point } \\
\text { but significantly increase } \\
\text { compared to control group }\end{array}$ \\
\hline & & & & & & ТВ & $45 \%$ & $\begin{array}{l}\mathrm{TB}+\text { above cut-off point and } \\
\text { significantly increase } \\
\text { compared to control group }\end{array}$ \\
\hline & & & & & & $\mathrm{AO}$ & $50 \%$ & $\begin{array}{l}\mathrm{AO}+\text { above cut-off point and } \\
\text { significantly increase } \\
\text { compared to control group }\end{array}$ \\
\hline \multirow[t]{4}{*}{$\begin{array}{l}\text { Pourentezari } \\
\text { et al. (2016) }\end{array}$} & \multirow[t]{4}{*}{ Mice } & \multirow[t]{4}{*}{8} & \multirow[t]{4}{*}{$\begin{array}{l}\text { Experimental } \\
\text { study }\end{array}$} & \multirow[t]{4}{*}{10 weeks } & \multirow[t]{4}{*}{$\begin{array}{l}\text { Water soluble, } 10 \\
\mathrm{mg} / \mathrm{kg}, 35 \text { days }\end{array}$} & $\mathrm{AB}$ & Not mentioned & $\begin{array}{l}\mathrm{AB}+\text { not significant } \\
\text { compared to control group }\end{array}$ \\
\hline & & & & & & CMA3 & & $\begin{array}{l}\text { CMA3+ significantly } \\
\text { increase compared to control } \\
\text { group }\end{array}$ \\
\hline & & & & & & ТВ & & $\begin{array}{l}\mathrm{TB}+\text { significantly increase } \\
\text { compared to control group }\end{array}$ \\
\hline & & & & & & $\mathrm{AO}$ & & $\begin{array}{l}\mathrm{AO}+\text { significantly increase } \\
\text { compared to control group }\end{array}$ \\
\hline \multirow[t]{3}{*}{$\begin{array}{l}\text { Ouko et al. } \\
\text { (2009) }\end{array}$} & \multirow[t]{3}{*}{$\begin{array}{l}\text { Semen } \\
\text { sample in } \\
\text { men }\end{array}$} & \multirow[t]{3}{*}{16} & \multirow[t]{3}{*}{$\begin{array}{l}\text { Prospective } \\
\text { study \& } \\
\text { questionairre }\end{array}$} & \multirow[t]{3}{*}{$\begin{array}{l}19 \text { to } 40 \\
\text { years }\end{array}$} & $\begin{array}{l}\text { Nondrinkers: } \\
\text { Teetotalers/ } \\
\text { abstained from } \\
\text { drinking alcohol for } \\
\text { the past } 3 \text { years }\end{array}$ & $\begin{array}{l}\mathrm{PCR} \\
\text { sequencing }\end{array}$ & $\begin{array}{l}\text { Demethylated: } \\
<25 \% \\
\text { methylated }\end{array}$ & \multirow[t]{3}{*}{$\begin{array}{l}\text { Chronic alcohol use } \\
\text { demethylated of normally } \\
\text { hypermethylated imprinted } \\
\text { region in sperm DNA }\end{array}$} \\
\hline & & & & & $\begin{array}{l}\text { Moderate drinkers: } 2 \\
\text { or } 3 \text { times/week with } \\
1 \text { to } 4 \text { drinks/session } \\
\text { OR } 1 \text { to } 2 \text { drinks/ } \\
\text { daily }\end{array}$ & & $\begin{array}{l}\text { Intermediate } \\
\text { methylation: } \\
25 \%-75 \% \\
\text { methylated }\end{array}$ & \\
\hline & & & & & $\begin{array}{l}\text { Heavy drinkers: } 2 \text { to } \\
4 \text { times/week with } 6 \\
\text { drinks/session }\end{array}$ & & & \\
\hline $\begin{array}{l}\text { Anifandis } \\
\text { et al. (2014) }\end{array}$ & $\begin{array}{l}\text { Semen } \\
\text { sample in } \\
\text { men }\end{array}$ & 83 & $\begin{array}{l}\text { Prospective } \\
\text { study \& } \\
\text { questionairre }\end{array}$ & $\begin{array}{l}37.43 \pm 0.3 \\
\text { years }\end{array}$ & $\begin{array}{l}\text { No alcohol users: } \\
\text { Not defined } \\
\text { Moderate alcohol } \\
\text { users }>0 \text { to }<7 \\
\text { units*/week } \\
\text { Heavy alcohol users } \\
>7 \text { units*/week }\end{array}$ & $\begin{array}{l}\text { SCD } \\
\text { (Halosperm) }\end{array}$ & Not mentioned & $\begin{array}{l}\text { Alcohol consumption with or } \\
\text { without confounding factor } \\
\text { of cigarette smoking could } \\
\text { cause deletrious effect on } \\
\text { sperm DNA }\end{array}$ \\
\hline
\end{tabular}

Note. $* 1$ alcohol unit was considered for $100 \mathrm{ml}$ wine, $200 \mathrm{ml}$ beer; $30 \mathrm{ml}$ whisky, $30 \mathrm{ml}$ vodka; AB: aniline blue; CMA3: chromomycin A3; TB: toluidine blue; AO: acridine orange; SCD: sperm chromatin dispersion assay. 


\section{Discussion}

\subsection{Preclinical Evidence}

The first animal study that will be reviewed used Long Evans and Sprague Dawley male rats. Its objectives were to assess the effect of strain, paternal and maternal alcohol consumption. The treatment group received a variation of ethanol concentration; 35\%,17\% and 0\%-ethanol derived calories (EDC). The study found out that paternal alcohol consumption resulted in decreased litter size and testosterone levels. Fortunately, it did not affect postnatal mortality and passive avoidance learning of offspring. On the same note, the rats strain affected their offspring activity. Ethanol 35\% consumption showed a decrement in offspring activity in Long Evans but increment in Sprague Dawley rats. In contrast, maternal ethanol consumption did not affect offspring activity but it was associated with lower birth rate, lower offspring weight at weaning, poorer passive avoidance learning and increased in postnatal mortality. Despite of the main design of the study, the study had selected sperm from Long Evans for their DNA study. Instead of using three doses tested in the main study design, only two doses were used for the sperm DNA damage evaluation, $0 \%$ and $35 \%$. They found out that sperm DNA from that strain migrated further compared to its control following ethanol consumption (Abel, 1989). However, this study failed to report the statistical analysis. Thus, the significance of 50 kilobase pairs between the tested group could not be concluded.

In another experimental study, alcohol abuse model used Wistar rats. This study is interesting because it took spermatogenesis cycle duration (50 days) into consideration. It also documented for the first time the effect of alcohol towards nuclear sperm DNA. They measured sperm motility and chromatin integrity from cauda epididymal aspiration. The study introduced a "cut-off" value for the cytochemical test done. Their findings showed that ethanol consumption did not affect sperm morphology but decreased its progressive and non-progressive motility. Even though they did not have a positive and negative control on the sperm DNA evaluation, this study did test the efficacy and quality of the stain by using acid denaturation method in a normal sample. This study found out that ethanol caused DNA damage and affected its chromatin integrity (Talebi et al., 2011).

Generally, many risk factors for infertility. Apart from alcohol, chronic diseases like diabetes has been associated with infertility too. Another experimental study that involved ethanol consumption in diabetes animal model has been established (Pourentezari et al., 2016). This study used male mice with streptozotocin $(200 \mathrm{mg} / \mathrm{kg}$, single dose, intraperitoneal) for diabetes induction. While considering diabetes a cofounding factor, this study used 35 days of ethanol liquid diet. This duration won't be able to complete a spermatogenesis cycle. However, the dose of ethanol liquid diet in supplemented in this study is higher (10 mg/kg compare to $5 \% \mathrm{v} / \mathrm{v})$ compared to the study done by Talebi, Sarcheshmeh, Khalili, and Tabibnejad (2011). Despite of this situation, the findings suggested that ethanol consumption with or without hyperglycemic state decreased all sperm parameters and affected sperm DNA integrity. Through AO staining, the study showed that alcoholism with or without diabetes as cofounding factor would increase denaturation of sperm single stranded DNA. While, TB and CMA3 stain confirmed that alcohol has a profound detrimental effect on sperm chromatin condensation.

\subsection{Clinical Evidence}

We reviewed two studies on human sample in this paper. The first study involved the evaluation of alcohol consumption with cigarette smoking as a cofounding factor (Anifandis et al., 2014). This study chosen sperm DNA fragmentation index (SDF) as their indicator and this were measured by using sperm chromatin dispersion (SCD) assay kit, Halosperm ${ }^{\circledR}$. Study concluded that smoking causes an irreversible damage to the DNA while sperm morphology was evidently suggested to be reversible upon discontinuation of alcohol consumption (Kuller et al., 1978). Yet, the reversibility of DNA damage upon alcohol discontinuation was not evaluated. The percentage of no halo which represent high percentage of DNA fragmentation was not significant between no alcoholics, moderate and heavy alcoholics group. On the other hand, there was significant difference of small halo percentage between moderate and heavy alcoholics group. Thus, the consumption of more than 7 units (1 alcohol unit was considered for $100 \mathrm{ml}$ wine $/ 200 \mathrm{ml}$ beer $/ 30 \mathrm{ml}$ whisky $/ 30 \mathrm{ml}$ vodka) of alcohol per week will be resulting in low percent of DNA damage. Even though, smoking and alcohol act independently, this study has concluded that both factors acted synergistically when combined.

In a second study of human sample, the paternal effect in the etiology of fetal alcohol spectrum disorder (FASD) was investigated. An irreversible cognitive and behavioral disability characterized the fetal alcohol spectrum disorder. Animal studies have shown that chronic paternal alcohol consumption has damaging effect on mental and physical offspring development without alcohol exposure during their uterine life. Primarily, FASD is attributed to maternal alcohol use during pregnancy but this study was to establish a link between alcohol use in 
men with methylation in sperm DNA. It has been documented that alcohol reduced DNA methyltransferases. This enzyme is a key enzyme that establish and maintain methylation pattern. The reduction of the enzyme activity leads to DNA hypomethylation and activation of normally silenced genes. The findings have shown that alcohol affected an important gene that regulate fetal development. It also has identified a useful method for studying paternal effect in inherited epigenetic modifications (Ouko et al., 2009).

Both human study has slightly different age of the subject. Age is one of the cofounding factors that contribute an important role in determining the status of DNA damage in human as aging has been proven scientifically as one of the factor that could contribute to higher sperm DNA damage in men (Das et al., 2013; Pharm et al., 2014). In prospective study involving human subject, age factor cannot be manipulated. Due to this age variation, it would be better if classification of age is done for further evaluation of alcohol doses on status of DNA damage in the future.

Based on this review, availability of study on the sperm DNA damage in association with alcohol consumption is very sparse. This situation claims a vast investigation in the future. Even though there were reports stating that conventional semen parameters could be reversible upon discontinuation of alcohol consumption (Vicari et al., 2002; Sermondade et al., 2010; Guthauser et al., 2014), conclusion of this same effect on the sperm DNA need to be further investigated in the future.

\section{References}

Abel, E. L. (1989). Paternal and maternal alcohol consumption: Effects on offspring in two strains of rats. Alcoholism: Clinical \& Experimental Research, 13(4), 533-541. https://doi.org/10.1111/j.1530-0277.1989. tb00373.x

Agarwal, A., \& Allamaneni, S. S. R. (2005). Sperm DNA damage assessment: A test whose time has come. Fertility \& Sterility, 84(4), 850-853. https://doi.org/10.1016/j.fertnstert.2005.03.080

Anifandis, G., Bounartzi, T., Messini, C. I., Dafopoulos, K., Sotiriou, S., \& Messinis, E. (2014). The impact of cigarette smoking and alcohol consumption on sperm parameters and sperm DNA fragmentation (SDF) measured by Halosperm ${ }^{\circledR}$. Archives of Gynecology and Obstetrics, 290(4), 777-782. https://doi.org/ 10.1007/s00404-014-3281-x

Bjelakovic, G., Nikolova, D., Gluud, L. L., Simonetti, R. G., \& Gluud, C. (2012). Antioxidant supplements for prevention of mortality in healthy participants and patients with various diseases. Cochrane Database of Systematic Reviews, 2. https://doi.org/10.1002/14651858.CD007176.pub2

Chen, H., \& Lina, H. (2016). Dopamine agonists for preventing future miscarriage in women with idiopathic hyperprolactinemia and recurrent miscarriage history. Cochrane Database of Systematic Reviews, 12. https://doi.org/10.1002/14651858.CD008883.pub2

Condorelli, R. A., Calogero, A. E., Vicari, E., \& La Vignera, S. (2014). Chronic consumption of alcohol and sperm parameters: Our experience and the main evidences. Andrologia, 47(4), 368-379. https://doi.org/ 10.1111/and.12284

Consales, C., Leter, G., Bonde, J. P. E., Toft, G., Eleuteri, P., Moccia, T., ... Spanò, M. (2014). Indices of methylation in sperm DNA from fertile men differ between distinct geographical regions. Human Reproduction, 29(9), 2065-2072. https://doi.org/10.1093/humrep/deu176

Das, M., Al-Hathal, N., San-Gabriel, M., Phillips, S., Kadoch, I. J., Bissonnette, F., ... Zini, A. (2013). High prevalence of isolated sperm DNA damage in infertile men with advanced paternal age. Journal of Assisted Reproduction and Genetics, 30(6), 843-848. https://doi.org/10.1007/s10815-013-0015-0

Farquhar, C., Rombauts, L. U. K., Kremer, J. A. M, Lethaby, A., \& Ayeleke, R. O. (2017). Oral contraceptive pill, progestogen or oestrogen pretreatment for ovarian stimulation protocols for women undergoing assisted reproductive techniques. Cochrane Database of Systematic Reviews, 5. https://doi.org/10.1002/14651858. CD006109.pub3

Garolla, A., Pizzol, D., Vasoin, F., Barzon, L., Bertoldo, A., \& Foresta, C. (2014). Counseling reduces HPV persistence in coinfected couples. Journal of Sexual Medicine, 11(1), 127-135. https://doi.org/10.1111/ jsm. 1235

Gaur, D. S., Talekar, M. S., \& Pathak, V. P. (2010). Alcohol intake and cigarette smoking: Impact of two major lifestyle factors on male fertility. Indian Journal of Pathology and Microbiology, 53(1), 35-40. https://doi.org/10.4103/0377-4929.59180 
Guthauser, B., Boitrelle, F., Plat, A., Thiercelin, N., \& Vialard, F. (2014). Chronic excessive alcohol consumption and male fertility: A case report on reversible azoospermia and a literature review. Alcohol and Alcoholism, 49(1), 42-44. https://doi.org/10.1093/alcalc/agt133

Hansen, M. L., Thulstrup, A. M., Bonde, J. P., Olsen, J., Hakonsen, L. B., \& Ramlau-Hansen, C. H. (2012). Does last week's alcohol intake affect semen quality or reproductive hormones? A cross-sectional study among healthy young Danish men. Reproductive Toxicology, 34(3), 457-462. https://doi.org/10.1016/j.reprotox. 2012.06.004

Hart, R. J., Doherty, D. A., McLachlan, R. I., Walls, M. L., Keelan, J. A., Dickinson, N. E., ... Handelsman, D. J. (2015). Testicular function in a birth cohort of young men. Human Reproduction, 30(12), 2713-2724. https://doi.org/10.1093/humrep/dev244

Jesen, T. K., Swan, S., Jørgensen, N., Toppari, J., Redmon, B., Punab, M., ... Andersson, A. M. (2014). Alcohol and male reproductive health: A cross-sectional study of 8344 healthy men from Europe and the USA. Human Reproduction, 29(8), 1801-1809. https://doi.org/10.1093/humrep/deu118

Joo, K. J., Kwon, Y. W., Myung, S. C., \& Kim, T. H. (2012). The effects of smoking and alcohol intake on sperm quality: Light and transmission electron microscopy findings. Journal of International Medical Research, 40(6), 2327-2335. https://doi.org/10.1177/030006051204000631

Kuller, L. H., May, S. J., \& Perper, J. A. (1978). The relationship between alcohol, lever disease, and testicular pathology. American Journal of Epidemiology, 108(3), 192-199. https://doi.org/10.1093/oxfordjournals. aje.a112611

Kunzle, R., Mueller, M. D., Hanggi, W., Birkhauser, M. H., Drescher, H., \& Bersinger, N. A. (2003). Semen quality of male smokers and nonsmokers in infertile couples. Fertility and Sterility, 79(2), $287-291$. https://doi.org/10.1016/S0015-0282(02)04664-2

Li, L., Dou, L., Leung, P. C., Chung, T. K. H., \& Wang, C. C. (2016). Chinese herbal medicines for unexplained recurrent miscarriage. Cochrane Database of Systematic Reviews, 6. https://doi.org/10.1002/14651858. CD010568.pub2

Li, Y., Lin, H., Ma, M., Li, L., Cai, M., Zhou, N., ... Cao, J. (2009). Semen quality of 1346 healthy men, results from the Chongqing area of southwest China. Human Reproduction, 24(2), 459-469. https://doi.org/ 10.1093/humrep/den399

Little, P. J., Adams, M. L., \& Cicero, T. J. (1992). Effects of alcohol on the hypothalamic-pituitary-gonadal axis in the developing male rat. Journal of Pharmacology and Experimental Therapeutics, 263(3), 1056-1061.

MacArthur, J. A. L., Spector, T. D., Lindsay, S. J., Mangino, M., Gill, R., Small, K. S., \& Hurles, M. E. (2014). The rate of nonallelic homologous recombination in males is highly variable, correlated between monozygotic twins and independent of age. PLoS Genetics, 10(3), e1004195. https://doi.org/10.1371/ journal.pgen.100419

Maneesh, M., Dutta, S., Chakrabarti, A., \& Vasudevan, D. M. (2006). Alcohol abuse-duration dependent decrease in plasma testosterone and antioxidants in males. Indian Journal of Physiology and Pharmacology, 50(3), 291-296.

Martini, A. C., Molina, R. I., Estofan, D., Senestrari, D., de Cunoe, M. F., \& Ruiz, R. D. (2004). Effect of alcohol and cigarette consumption on human seminal quality. Fertility and Sterility, 82(2), 374-377. https://doi.org/ 10.1016/j.fertnstert.2004.03.022

Muthusami, K. R., \& Chinnaswamy, P. (2005). Effect of chronic alcoholism on male fertility hormones and semen quality. Fertility and Sterility, 84(4), 919-924. https://doi.org/10.1016/j.fertnstert.2005.04.025

Nicoletti, A., Petersen, C. G., Mauri, A. L., Vagnini, L. D., Renzi, A., Oliveira-Pelegrin, G. R., ... Franco Jr., J. G. (2016). Semen parameters in men with varicocele: DNA fragmentation, chromatin packaging, mitochondrial membrane potential, and apoptosis (Vol. 31, i79). Human Reproduction, Conference: 32nd annual meeting of the European society of human reproduction and embryology, Finland. https://doi.org/10.1093/humrep/31.Supplement_1.1

Nisenblat, V., Bossuyt, P. M. M., Shaikh, R., Farquhar, C., Jordan, V., Scheffers, C. S., ... Hull, M. L. (2016). Blood biomarkers for the non-invasive diagnosis of endometriosis. Cochrane Database of Systematic Reviews, 5. https://doi.org/10.1002/14651858.CD012179 
Ouko, L. A., Shantikumar, K., Knezovich, J., Haycock, P., Schnugh, D. J., \& Ramsay, M. (2009). Effect of alcohol consumption on $\mathrm{CpG}$ methylation in the differentially methylated regions of H19 and IG-DMR in male gametes: Implications for fetal alcohol spectrum disorders. Alcoholism: Clinical \& Experimental Research, 33(9), 1615-1627. https://doi.org/10.1111/j.1530-0277.2009.00993.x

Perreault, S. D., Aitken, R. J., Baker, H. W., Evenson, D. P., Huszar, G., Irvine, D. S., ... Wyrobek, A. J. (2003). Integrating new tests of sperm genetic integrity into semen analysis: Breakout group discussion. Advances in Experimental Medicine and Biology, 518,253-268. https://doi.org/10.1007/978-1-4419-9190-4_23

Pharm, S. B., Benkhlifa, M., Cohen-Bacrie, M., Dalleac, A., Amar, E., \& Zini, A. (2014). Sperm deoxyribonucleic acid damage in normozoospermic men is related to age and sperm progressive motility. Fertility and Sterility, 101(6), 1588-1593. https://doi.org/10.1016/j.fertnstert.2014.02.006

Pourentezari, M., Talebi, A. R., Mangoli, E., Anvari, M., \& Rahimipour, M. (2016). Additional deleterious effects of alcohol consumption on sperm parameters and DNA integrity in diabetic mice. Andrologia, 48(5), 564-569. https://doi.org/10.1111/and.12481

Pourmand, G., Movahedin, M., Dehghani, S., Mehrsai, A., Ahmadi, A., Pourhosein, M., ... Noria, M. (2014). Does 1-carnitine therapy add any extra benefit to standard inguinal varicocelectomy in terms of deoxyribonucleic acid damage or sperm quality factor indices: A randomized study. Urology, 84(4), 821-825 https://doi.org/10.1016/j.urology.2014.07.006

Povey, A. C., Clyma, J. A., McNamee, R., Moore, H. D., Baillie, H., Pacey, A. A., \& Cherry, N. M. (2012). Modifiable and non-modifiable risk factors for poor semen quality: A case-referent study. Human Reproduction, 27(9), 2799-2806. https://doi.org/10.1093/humrep/des183

Rubes, J., Lowe, X., Moore, D., Perreault, S., Slott, V., Evendon, D., ... Wyrobek, A. J. (1998). Smoking cigarettes is associated with increased sperm disomy in teenage men. Fertility and Sterility, 70(4), 715-723. https://doi.org/10.1016/S0015-0282(98)00261-1

Sermondade, N., Elloumi, H., Berthaut, I., Mathieu, E., Delarouziere, V., Raver, C., \& Mandelbaum, J. (2010). Progressive alcohol-induced sperm alterations leading to spermatogenic arrest, which was reversed after alcohol withdrawal. Reproductive BioMedicine, 20(3), 324-327. https://doi.org/10.1016/j.rbmo.2009.12.003

Showell, M. G., Brown, J., Clarke, J., \& Hart, R. J. (2013). Antioxidants for female subfertility. Cochrane Database of Systematic Reviews, 8. https://doi.org/10.1002/14651858.CD007807.pub2

Showell, M. G., Mackenzie-Proctor, R., Brown, J., Yazdani, A., Stankiewicz, M. T., \& Hart, R. J. (2014). Antioxidants for male subfertility. Cochrane Database of Systematic Reviews, 12. https://doi.org/10.1002/ 14651858.CD007411.pub3

Skalkidou, A., Sergentanis, T. N., Gialamas, S. P., Georgakis, M. K., Psaltopoulou, T., Trivella, M., ... Petridou, E. (2017). Risk of endometrial cancer in women treated with ovary-stimulating drugs for subfertility. Cochrane Database of Systematic Reviews, 3. https://doi.org/10.1002/14651858.CD010931.pub2

Talebi, A. R., Sarcheshmeh, A. A., Khalili, M. A., \& Tabibnejad, M. (2011). Effects of ethanol consumption on chromatin condensation and DNA integrity of epididymal spermatozoa in rat. Alcohol, 45(4), 403-409. https://doi.org/10.1016/j.alcohol.2010.10.005

Teijon, M. L., Garcia, F., Serra, O., Moragas, M., Rabanal, A., Olivares, R., \& Alvarez, J. G. (2007). Semen quality in a population of volunteers from the province of Barcelona. Reproductive BioMedicine Online, 15(4), 434-444. https://doi.org/10.1016/S1472-6483(10)60370-7

Van, Z. E. J., Fedorowicz, Z., Christensen, R., Lavrijsen, A. P. M., \& Arents, B. W. M. (2017). Emollients and moisturisers for eczema. Cochrane Database of Systematic Reviews, 2. https://doi.org/10.1002/14651858. CD012119.pub2

Varshini, J., Srinag, B. S., Kalthur, G., Krishnamurthy, H., Kumar, P., Rao, S. B. S., \& Adiga, S. K. (2012). Poor sperm quality and advancing age are associated with increased sperm DNA damage in infertile men. Andrologia, 44(Suppl. 1), 642-649. https://doi.org/10.1111/j.1439-0272.2011.01243.x

Vicari, E., Arancio, A., Giuffrida, V., D’Agata, R., \& Calogero, A. E. (2002). A case of reversible azoospermia following withdrawal from alcohol consumption. Journal of Endocrinology Investigation, 25(5), 473-46. https://doi.org/10.1007/BF03344041 


\section{Copyrights}

Copyright for this article is retained by the author(s), with first publication rights granted to the journal.

This is an open-access article distributed under the terms and conditions of the Creative Commons Attribution license (http://creativecommons.org/licenses/by/4.0/). 